Buletin Peternakan Tropis

Bulletin of Tropical Animal Science

Doi: https://doi.org/10.31186/bpt.2.2.83-89
Bul. Pet. Trop. 2(2): 83-89, 2021

e-ISSN: $2722-0788$

p-ISSN: 2722-1733

\title{
Suplementasi Tepung Kunyit (Curcuma domestica) dalam Ransum terhadap Kualitas Telur Ayam Ras Petelur
}

\author{
(Turmeric Powder (Curcuma domestica) Supplementation in Ration on Egg Quqlity of Laying \\ Chickens)
}

Mariati Komala Sari ${ }^{1}$, Desia Kaharuddin ${ }^{1 *}$, dan Warnoto ${ }^{1}$

${ }^{1}$ Jurusan Peternakan, Fakultas Pertanian, Universitas Bengkulu, JI W.R. Supratman, Kandang Limun, Bengkulu 38371A

*Penulis Korespondensi: (desiakaharuddin6@gmail.com)

Dikirim (received): 03 September 2021; dinyatakan diterima (accepted): 28 Oktober 2021; terbit (published): 15 November 2021. Artikel ini dipublikasi secara daring pada https://ejournal.unib.ac.id/index.php/buletin_pt/index

\begin{abstract}
This study aimed to analyze the effect of turmeric powder supplementation in the ration on the egg quality of laying hens. Forty chickens aged 36 weeks were randomly distributed into four treatments, each treatment consisted of 10 replications as follows: Treatment (P0) was without turmeric powder supplementation, the other treatment was turmeric powder supplementation (P1: 0.75\%, P2: 1.5\% and P3: 2.25\%). A completely randomized design used in the study. Variables observed were yolk color, yolk index, albumen index, Haugh Unit, and shell thickness. The study was conducted for nine weeks. The data obtained were analyzed by Analysis of Variance, and if there was a significant effect $(P<0.05)$ was further tested using Duncan's Multiple Range Test. The results showed that turmeric powder supplementation had a significant effect $(P<0.05)$ on the egg yolk color with the highest score of 7.9 produced by P3 $(2.25 \%$ turmeric flour), and the results of the analysis showed that turmeric powder supplementation up to $2.25 \%$ had no significant effect $(P>0.05)$ on yolk index, albumen index, haught unit and egg shell. The mean egg yolk index was $0.45-0.50$, the average albumen index was $0.120-0.135$, the average Haugh unit was 96.53 - 99.58, the average egg shell was 0.38 - 0.41. The results of the study, it was concluded that supplementation of turmeric flour in the ration up to a level of $2.25 \%$ could increase egg yolk color, but could not increase egg yolk index, albumen index, Haugh unit and egg shell.
\end{abstract}

Key words: turmeric powder, egg quality, layer chickens

\section{ABSTRAK}

Tujuan penelitian ini adalah mengevaluasi pengaruh suplementasi tepung kunyit dalam ransum terhadap kualitas telur ayam ras petelur. Empat puluh ekor ayam umur 36 minggu didistribusikan secara acak ke dalam empat perlakuan, masing-masing perlakuan terdiri 10 ulangan sebagai berikut: Perlakuan (PO) tanpa suplementasi tepung kunyit, perlakuan lainnya adalah suplementasi tepung kunyit ( P1: 0,75\%, P2 : 1,5\% dan P3 : 2,25\%). Rancangan yang digunakan adalah Rancangan Acak Lengkap. Variabel diamati warna kuning telur, indeks kuning telur, indeks albumen, haugh unit, dan tebal kerabang. Pengamatan kualitas telur dilakukan pada minggu ke Sembilan. Data yang terkumpul dianalisis dengan Analisis of Variance. Hasil penelitian menunjukkan bahwa suplementasi tepung kunyit berpengaruh nyata $(P<0,05)$ terhadap warna kuning telur dengan skor tertinggi 7,9 yang dihasilkan oleh P3. Hasil analisis suplementasi tepung kunyit sampai $2,25 \%$ tidak berpengaruh secara nyata $(P>0,05)$ terhadap indeks kuning telur, indeks albumen, haught unit dan tebal kerabang. Rataan indeks kuning telur 0,45-0,50, rataan indeks albumen 0,120 0,135 , rataan haugh unit 96,53 - 99,58, rataan tebal kerabang 0,38-0,41. Berdasarkan hasil penelitian disimpulkan bahwa suplementasi tepung kunyit dalam ransum sampai level 2,25\% dapat meningkatkan 
warna kuning telur, tetapi tidak dapat meningkatkan indeks kuning telur, indeks albumen, haugh unit dan tebal kerabang.

Kata kunci: tepung kunyit, kualitas telur, ayam ras

\section{PENDAHULUAN}

Telur merupakan produk utama yang dihasilkan oleh ternak unggas petelur seperti ayam, itik, dan puyuh. Menurut Indrawan et al., (2012) telur merupakan bahan pangan yang sempurna, karena mengandung zat gizi seperti protein, lemak, vitamin dan mineral dalam jumlah cukup untuk memenuhi kebutuhan makhluk hidup. Telur mengandung asam amino esensial yang lengkap sehingga telur digunakan sebagai standar dalam menentukan mutu protein berbagai bahan pangan. Telur merupakan makanan ideal, yang sangat mudah didapatkan dan selalu tersedia setiap saat.

Ketersediaan produk berupa telur selain nilai gizinya perlu diperhatikan juga kualitasnya baik kualitas eksternal maupun internal. Kualitas eksternal yaitu lebar telur, panjang telur, kerabang, dan ukuran telur, sedangkan kualitas internal telur yaitu warna kuning telur, indeks kuning telur, indeks albumen, dan haugh unit. Untuk mendapatkan telur yang berkualitas baik biasanya peternak menambahkan feed supplement komersial dalam ransum untuk melengkapi nutrisi ransum yang digunakan. Akhir-akhir ini telah dikembangkan berbagai tanaman obat sebagai pengganti feed suplement komersil. Salah satu tanaman obat yang berpotensi untuk digunakan sebagai pengganti.

Kunyit (Curcuma domestica) merupakan salah satu dari tanaman obat yang dapat digunakan sebagai feed suplement atau feed additive, serta memiliki kandungan gizi yang baik dan dapat dicampurkan ke dalam ransum unggas (Pratikno, 2010). Kunyit mengandung fitoestrogen yang berfungsi sama seperti estrogen dalam tubuh (Clarkson, 2002). Estrogen pada unggas petelur berfungsi untuk perkembangan folikel, sehingga apabila folikel banyak yang berkembang, maka kolesterol sebagai materi pembentuk kuning telur akan terdistribusi secara merata ke seluruh folikel sehingga kadar kolesterol dalam telur menjadi berkurang. Estrogen akan semakin meningkat seiring dengan pertumbuhan folikel ovarium mulai berkembang menjelang dewasa kelamin. Tingginya estrogen pada masa kelamin akan berpengaruh terhadap pertumbuhan dan pembentukan kuning telur.

Kunyit mengandung kurkumin dan minyak atsiri yang memiliki fungsi untuk meningkatkan sekresi cairan empedu (kalagoga) untuk meningkatkan nafsu makan, (kurkuminoid) dipercaya dapat memberikan pengaruh terhadap warna kuning telur (Purwanti, 2008). Zat aktif berupa kurkumin dalam kunyit berperan sebagai antibakteri, yang berfungsi menghambat produksi $\beta$ lactamase dari mikroorganisme untuk membentuk dinding sel (Kumar et al., 2006). Selanjutnya Nasir et al. (2016) menyatakan bahwa zat kurkumin yang terkandung dalam kunyit dapat merangsang dinding kantung empedu untuk mengeluarkan cairan empedu, cairan empedu dapat memperlancar metabolisme lemak dalam tubuh.

Berdasarkan uraian di atas dilakukan penelitian yang bertujuan untuk menganalisis pengaruh suplementasi tepung kunyit (Curcuma domestica) dalam ransum terhadap kualitas telur ayam ras petelur. Diduga suplementasi kunyit dapat meningkatkan kualitas telur ayam.

\section{BAHAN DAN METODE}

Pembuatan Tepung Kunyit

Rimpang kunyit dicuci bersih kemudian dikupas dan diiris tipis-tipis. Hasil irisan dijemur sampai kering dan kemudian digiling menjadi tepung dan tepung kunyit siap digunakan. 
Tabel 1. Formulasi dan kandungan nutrisi ransum percobaan

\begin{tabular}{lcccc}
\hline \multirow{2}{*}{ Bahan Pakan } & \multicolumn{4}{c}{ Perlakuan } \\
\cline { 2 - 5 } & P0 & P1 & P2 & P3 \\
\hline Dedak & 21 & 21,25 & 20,50 & 19,75 \\
Jagung Kuning & 41,5 & 41,5 & 41,5 & 41,5 \\
KLK & 35 & 35 & 35 & 35 \\
Mineral Mix & 1,5 & 1,5 & 1,5 & 1,5 \\
Top Mix & 1 & 0 & 0 & 0 \\
Tepung Kunyit (TK) & 0 & 0,75 & 1,5 & 2,25 \\
\hline Total & 100 & 100 & 100 & 100 \\
\hline Kandungan Nutrisi : & & & & \\
Protein Kasar (\%) & 17,34 & 17,42 & 17,41 & 17,39 \\
ME (Kkal/kg) & 2703,31 & 2718,94 & 2716,46 & 2713,99 \\
Lemak Kasar (\%) & 4,75 & 4,83 & 4,87 & 4,92 \\
Serat Kasar (\%) & 4,48 & 4,58 & 4,50 & 4,42 \\
Ca (\%) & 4,31 & 4,32 & 4,320 & 4,32 \\
P (\%) & 0,90 & 0,91 & 0,90 & 0,90 \\
\hline
\end{tabular}

Keterangan: P0:ransum kontrol tanpa Suplementasi Tepung Kunyit, P1: Suplementasi 0,75\%, P2: Suplementasi 1,5\% dan P3: Suplementasi 2,25\% Tepung Kunyit.

\section{Ayam dan Pakan}

Penelitian ini menggunakan Rancangan Acak Lengkap. Sebanyak 40 ekor ayam ras petelur didistribusikan secara acak ke dalam empat macam perlakuan sebagai berikut: PO : perlakuan diberi ransum tanpa suplementasi tepung kunyit (kontrol); P1 : perlakuan ransum dengan suplementasi tepung kunyit 0,75\%; P2 : perlakuan ransum dengan suplementasi tepung kunyit 1,5\% dan; P3 : perlakuan ransum dengan suplementasi $2,25 \%$ tepung kunyit. Masing-masing perlakuan terdiri dari 10 ulangan. Formula dan kandungan nutrisi ransum yang dicobakan dalam penelitian ini disajikan pada Tabel 1.

Penelitian suplemen tepung kunyit berlangsung selama sembilan minggu, dan pengamatan kualitas telur dilakukan pada minggu ke sembilan. Pengamatan kualitas telur menggunakan 80 butir telur masingmasing perlakuan 20 butir. Adapun variabel yang diukur adalah warna kuning telur, indeks kuning telur, indeks albumen, haugh unit dan tebal kerabang.Warna kuning telur dengan cara membandingkan warna kuning telur warna standar dari yolk colour fan. Indeks kuning telur diukur dengan cara membandingkan tinggi kuning telur dengan diameter kuning telur, tingginya diukur menggunakan alat modifikasi tripod micrometer. Indeks albumen diukur dengan membandingkan tinggi albumen dengan rataan diameter albumen pekat dan albumen encer. Haugh unit dihitung berdasarkan hubungan logaritmik antara tinggi albumen (mm) dengan berat telur (gram) kemudian dimasukkan ke dalam Rumus $\mathrm{HU}=100 \log$ (h $+7,57-1,7$. W0,37) dan untuk menentukan tebal kerabang dengan cara mengukur tebal kerabang dengan alat jangka sorong. Pengamatan kualitas telur menggunakan 80 butir telur masing-masing perlakuan 20 butir.

\section{Analisis Data}

Data yang diperoleh dianalisis dengan Analysis of Varian pada taraf kepercayaan $95 \%$. Jika berpengaruh secara nyata $(P<0,05)$ maka uji dilanjutkan dengan menggunakan Duncan Multiple Range Test.

\section{HASIL DAN PEMBAHASAN}

\section{Warna Kuning Telur}

Pengaruh suplementasi tepung kunyit terhadap kualitas telur disajikan pada Tabel 2. Hasil ANOVA menunjukkan bahwa 
suplementasi tepung kunyit berpengaruh nyata $(P<0,05)$ terhadap warna kuning telur. Berdasarkan uji DMRT rataan warna kuning telur perlakuan tanpa suplementasi tepung kunyit nyata lebih rendah dari semua perlakuan yang mendapat suplementasi. Diantara perlakuan yang mendapat suplementasi tepung kunyit (P1, P2 dan P3) tidak berbeda nyata namun terlihat bahwa semakin tinggi level suplementasi semakin tinggi pula skor warna kuning telur yang dihasilkan. Skor warna kuning telur yang dihasilkan berkisar 6,9-7,9 yang tertinggi dihasilkan oleh P3 $(7,9)$. Menurut Yamamoto et al., (1997) kandungan karoten dalam ransum akan mempengaruhi warna kuning telur, semakin tinggi karoten yaitu xantofil, warna kuning telur semakin jingga kemerahan.

Tabel 2. Rataan pengaruh suplementasi tepung kunyit (Curcuma domestica) dalam ransum terhadap warna kuning telur, indeks kuning telur, indeks albumen, haugh unit dan tebal kerabang telur ayam ras petelur

\begin{tabular}{|c|c|c|c|c|c|}
\hline \multirow{2}{*}{ Variabel } & \multicolumn{4}{|c|}{ Indeks kuning telur } & \multirow[b]{2}{*}{ Ket. } \\
\hline & PO & $\mathrm{P} 1$ & P2 & P3 & \\
\hline Warna kuning telur & $6,9^{a}$ & $7,5^{b}$ & $7,8^{b}$ & $7,9^{b}$ & * \\
\hline Indeks kuning telur & 0,54 & 0,54 & 0,54 & 0,53 & ns \\
\hline Indeks albumen & 0,15 & 0,13 & 0,14 & 0,14 & ns \\
\hline Haugh unit & 96 & 96 & 96 & 98 & ns \\
\hline Tebal kerabang & 0,36 & 0,38 & 0,37 & 0,36 & ns \\
\hline
\end{tabular}

Keterangan: Superscript berbeda pada baris yang sama menunjukkan berbeda nyata $(P<0,05)$ P0:ransum kontrol tanpa Suplementasi Tepung Kunyit, P1: Suplementasi 0,75\% P2: Suplementasi 1,5\% dan P3: Suplementasi 2,25\% Tepung Kunyit

Dalam penelitian ini bahan yang mengandung sumber karoten adalah jagung giling. Pada penelitian ini penggunaan jagung untuk semua perlakuan yaitu $41,5 \%$ maka kontribusi xantophil terhadap warna kuning telur untuk setiap perlakuan dalam penelitian ini juga sama, berdasarkan hal tersebut maka perbedaan warna kuning telur dalam penelitian disebabkan oleh kurkumin yang terdapat pada kunyit. Terdapat kecenderungan bahwa semakin tinggi level suplementasi tepung kunyit semakin tinggi skor warna kuning telur. Amrullah (2004) menyatakan, warna kuning telur mencapai skor 7-8 skala Roche digolongkan ke dalam kualitas baik. Warna kuning telur hasil pada penelitian ini berkisar 6,9 sampai 7,9 dan warna masih dalam kategori baik.

\section{Indeks Kuning Telur}

Hasil analisis ragam menunjukkan bahwa suplementasi tepung kunyit dalam ransum berpengaruh tidak nyata $(P>0,05)$ terhadap indeks kuning telur. Indeks kuning telur hasil penelitian 0,53-0,54. Indeks kuning telur akan menurun dengan masuknya air dan putih telur ke dalam kuning telur sebagai akibat adanya perbedaan tekanan osmosis antara putih telur dan kuning telur, sehingga kuning telur menjadi encer. Menurut BSN (2008) tingkatan mutu indeks kuning telur 0,45-0,52 (Mutu I), 0,39-0,45 (Mutu II), dan 0,33-0,39 (Mutu III). Sudaryani (2003) menyatakan indeks kuning telur merupakan indeks mutu kesegaran yang diukur dari tinggi dan diameter kuning telur. Telur segar mempunyai indeks kuning telur 0,33-0,50 dengan rata-rata 0,42 (Koswara, 2009). Berdasarkan hasil indeks kuning telur berkisar antara 0,45-0,50 termasuk pada kategori Mutu I. Faktor yang mempengaruhi indeks kuning telur antara lain ukuran telur, lama penyimpanan, dan nutrisi pakan.

\section{Indeks Albumen}

Hasil perhitungan indeks albumen pada minggu ketiga sampai minggu kesembilan dapat dilihat pada Tabel 2. Suplementasi tepung kunyit sampai $2,25 \%$ tidak 
berpengaruh secara nyata $(P>0,05)$ terhadap indeks albumen. Pada penelitian ini Indeks albumen berkisar 0,13-0,15. Standar grade indeks albumen telur grade I berkisar antara 0,134-0,175, grade II berkisar antara 0,0920,133 dan grade terakhir yaitu berkisar antara 0,050-0,091 (BSN, 2008). Rataan indeks albumen selama penelitian ini masih dalam kisaran normal yaitu grade II dengan nilai 0,120-0,135. Samli et al. (2005) menjelaskan bahwa adanya penuruan indeks albumen disebabkan karena hilangnya $\mathrm{CO}_{2}$ dan terjadinya pemecahan asam karbonat menjadi $\mathrm{CO}_{2}$, sehingga menyebabkan serat mucin kehilangan struktur yang memberikan tekstur kental pada albumen telur, sehingga albumen menjadi encer.

\section{Haugh Unit}

Haugh unit merupakan satuan yang digunakan untuk mengetahui kesegaran isi telur, terutama pada bagian putih telur. Hasil analisis menunjukkan bahwa suplemen tepung kunyit dalam ransum berpengaruh tidak nyata $(P>0,05)$ terhadap haugh unit, diduga tepung kunyit tidak berpengaruh langsung dalam proses pembentukan albumen telur. Protein albumen terdiri dari protein serabut yaitu ovomusin yang berperan dalam pengikatan air untuk membentuk gel albumen. Semakin banyak dan kuat jala-jala ovomusin maka viskositas albumen semakin tinggi dan semakin tinggi viskositas albumen dan akan meningkatkan nilai haugh unit (Roesdiyanto et al., 2001).

Haugh Unit (HU) telur dengan kualitas $A A$ (72 sampai 100), B (60 sampai 71), C (di bawah 29) USDA (2000). Telur dengan mutu yang baik mempunyai HU minimal 72 . Telur yang tidak layak dikonsumsi mempunyai HU kurang dari 30 (Koswara, 2009). Berdasarkan hasil pengamatan nilai rata-rata haugh unit selama penelitian yaitu sebesar 96-99 tergolong kualitas (AA).

Menurut Sudaryani (2003), nilai HU merupakan nilai yang menggambarkan kekentalan albumen, semakin kecil nilai haugh unit maka semakin encer albumen sehingga kualitas nya semakin rendah. Stadellman dan Cotteril (1995) menyatakan bahwa faktor yang mempengaruhi nilai $\mathrm{HU}$ adalah tinggi albumen dan berat telur sedangkan tinggi albumen sangat ditentukan oleh kepadatan albumen. Kepadatan albumen itu sendiri dipengaruhi oleh kandungan protein dalam ransum yang dikonsumsi. Semakin tinggi albumen maka semakin tinggi nilai HU yang dihasilkan. Penelitian suplementasi dalam ransum tidak mempengaruhi indeks albumen sehingga nilai HU juga menunjukkan pengaruh yang tidak nyata.

\section{Tebal Kerabang}

Hasil analisis ragam menunjukkan bahwa suplementasi tepung kunyit dalam ransum berpengaruh tidak nyata $(P>0,05)$ terhadap tebal kerabang. Sudaryani (2003) menyatakan bahwa standar tebal kerabang ayam ras petelur adalah 0,40-0,51 $\mathrm{mm}$. Tebal kerabang yang dihasilkan pada penelitian ini berkisar antara 0,40-0,41 $\mathrm{mm}$ dan termasuk standar ukuran normal tebal kerabang. Penggunaan Suplementasi tepung kunyit dalam ransum tidak berpengaruh terhadap tebal kerabang, hal ini disebabkan karena kandungan Ca dan $\mathrm{P}$ dalam ransum pada masing-masing perlakuan hampir sama. Penggunaan tepung kunyit dalam ransum dapat meningkatkan proses penyerapan seperti kalsium (Ca) untuk membentuk kerabang telur, (Winarno, 2003). Selain itu unggas yang diberi pakan dengan kandungan kalsium yang tinggi, biasanya menghasilkan kerabang telur yang tebal. Faktor yang mempengaruhi kualitas kerabang telur yaitu ketebalan dan struktur kerabang. Pakan yang mengandung $\mathrm{Ca}, \mathrm{P}$, dan ion karbonat sangat mempengaruhi proses pembentukan kualitas kerabang telur (Anggorodi, 2009), semakin tinggi kualitas kalsium maka kualitas kerabang telur semakin baik (Clunies et al., 1992).

Muharlien et al., (2011) menyatakan bahwa kekurangan kalsium dan phosfor dalam pakan menghasilkan kerabang telur yang tipis yang 
mengakibatkan telur mudah retak dan menyebabkan bakteri mudah masuk kebagian dalam telur. Rahadianto et al., (2013) juga menyatakan tebal kerabang juga dipengaruhi oleh jenis ternak, strain dan suhu lingkungan. Tebal kerabang juga dipengaruhi oleh vitamin D, kadar vitamin D yang cukup diperlukan untuk mengabsorbsi kalsium dalam proses pembentukan tebal kerabang. Kerabang telur merupakan bagian terluar dari telur dan penting untuk diperhatikan kualitasnya, karena kerabang telur berfungsi melindungi isi telur dari masuknya bakteri penyebab kerusakan isi telur yang dapat mengakibatkan menurunnya kualitas telur (Amo et al., 2013)

\section{KESIMPULAN}

Berdasarkan hasil penelitian dapat disimpulkan bahwa penggunaan tepung kunyit (Curcuma domestica) dalam ransum sampai level $2,25 \%$ dapat meningkatkan warna kuning telur, tetapi tidak dapat meningkatkan indeks kuning telur, indeks albumen, Haugh Unit (HU), tebal kerabang dan tinggi rongga udara.

\section{DAFTAR PUSTAKA}

Amo, M., J. L. P. Saerang, M. Najoan dan J. Keintjem. 2013. Pengaruh penambahan tepung kunyit (Curcuma domestica Val) dalam ransum terhadap kualitas telur puyuh (Coturnix-coturnix japonica). Jurnal Zootek.33 (1) 8-57

Anggorodi, R. 2009. Kemajuan Mutakhir dalam IImu Makanan Ternak Unggas. UI Press. Jakarta.

Badan Standardisasi Nasional. 2008. SNI ISO 9001:2008: Sistem Manajemen MutuPersyaratan. Jakarta.

Chung, T. K. 2002. Yellow and red carotenoids for eggs yolk pigmentation. 10th Annual SA Southeast Asian Feed Technology and Nutrition Workshop. Merlin Beach Resort, Phuket, Thailand.

Clarkson, T. B. 2002. Fourth international symposium on the role of soy in preventing and treating chronic disease. J.
Nut. 132: 559S-565S.

Clunies M. D. Parks and S. Lesson. 1992. Calcium and phosphorus metabolism and egg shell formation of hens fed different amounts of calcium. Poultry Sci. 71: 482489.

Hartadi, H.,S. Reksohadiprodjo dan A. D. Tilman. 2005. Tabel Komposisi Pakan untuk Indonesia. Gadjah Mada University Press. Yogyakarta.

Indrawan, I. G., I. M. Sukada dan I. K. Suada. 2012. Kualitas telur dan pengetahuan masyarakat tentang penanganan telur di tingkat rumah tangga. Indonesia Medicus Veterinus, [S.I.], jan. 2013. ISSN 2477-6637.

Koswara, S. 2009. Teknologi Pengolahan Telur. http://tekpan.unimus.ac.id/wpcontent/uploads/2013/07/TEKNOLOGIPENGOLAHAN-TELUR.pdf.

Kumar, V. dan S. K. Sharnya. 2006. Antioxidant studies on some plants. Hamdar Medius Xlix (4) 25-36.

Muharlien, V. dan M. H. Natsir. 2011. Efek penambahan tepung kulit nanas (Ananas comosus (I) merr.) dalam pakan terhadap jumlah telur dan kualitas telur itik. Jurnal Ilmu dan Teknologi Hasil Ternak 6 (2): 5-14.

Pratikno, H. 2010. Pengaruh ekstrak kunyit (Curcuma domestica Val) terhadap bobot badan ayam broiler. Buletin Anatomi dan Fisiologi, 18 (2): 39-48.

Purwanti. 2008. Kajian efektifitas pemberian kunyit, bawang putih dan mineral zink terhadap performa, kadar lemak, kolesterol dan status kesehatan Broiler. Thesis. Sekolah Pascasarjana. Institut Pertanian Bogor.

Rahadianto, A., O. Sjofjan dan I. H. Djunaidi. 2013. Efek penambahan beberapa sumber kalsium dalam pakan terhadap kualitas eksternal telur ayam petelur. Fakultas Peternakan Universitas Brawijaya. Malang.

Roesdiyanto, Rosidi dan I. Suswoyo. 2001. Kualitas telur itik Tegal yang dipelihara secara intensif dengan berbagai tingkat kombinasi methionine-lancang dalam 
pakan. Lokakarya Nasional Unggas Air 2001. Hal. 111-117.

Samli, H. E., A. Agma dan N. Senkoylu.2005. Effects of storage time and temperature on egg quality in old laying hens J. Appl.Poult Res. 14: 548-553.

Saputra, D. R. 2016. Pengaruh penambahan feed aditif dalam ransum dengan dosis yang berbeda terhadap bobot telur dan nilai haugh unit (hu) telur ayam ras. Skripsi. Jurusan Peternakan, Fakultas Pertanian, Universitas Lampung.

Stadellman, W. J. dan O. J. Cotteril. 1995. Egg Science and Technology. Fourt Ed Food Product Press. An Imprint of the Haworth Press. Inc. New York. London.

Sudaryani, T. 2003. Perlakuan Telur Sebelum
Ditetaskan. Dalam: Mengatasi Permasalahan Beternak Ayam. Penebar Swadaya, Jakarta

Udedibie, A. B. I. dan C. C. Opara. 1998. Responses of gowing of broiler and laying hens to the dietary inclusion of leaf meal from Alchornia Cordifilia. Anim. Feed Sci. Technol. 71 : 157-164.

Unites State Departement of Agriculture USDA. 2000. Egg- grading Manual. Departement of Agriculture, Washington.

Winarno, F. G. 2003. Pangan, Gizi,Teknologi dan Konsumen. Gramedia : Jakarta.

Yamamato T., L. R. Juneja, H. Hatta dan M. Kim. 2007. Hen Eggs: Basic and Appllied Science. Universitas of Alberta, Can 